\title{
Consumo e Digestibilidade Total e Parcial de Dietas Utilizando Farelo de Girassol e Três Fontes de Energia em Novilhos Confinados ${ }^{1}$
}

\section{Ana Rosália Mendes ${ }^{2}$, Jane Maria Bertocco Ezequiel ${ }^{3}$, Rosemary Laís Galati ${ }^{4}$, Adriana Luize Bocchi $^{5}$, Mário Adriano Ávila Queiróz ${ }^{6}$, José Valmir Feitosa ${ }^{4}$}

RESUMO - Avaliaram-se o consumo alimentar, a digestibilidade parcial e total e o balanço de nitrogênio, em novilhos confinados. Foram utilizados três novilhos de corte cruzados, canulados no rúmen e no duodeno, distribuídos em dois delineamentos em quadrado latino 3 x 3 . As dietas experimentais foram constituídas de $60 \%$ de silagem de milho, tendo como fonte de proteína o farelo de girassol e, como fonte de energia, o milho (MI). O milho foi substituído parcialmente pela casca de soja (CS) ou pelo farelo de gérmen de milho (FGM). Quatro indicadores internos (lignina e FDA, FDN e lignina indigestíveis) foram submetidos a 144 horas de digestão in vitro, para estimativa da digestibilidade parcial e total das dietas. Houve maior ingestão dos componentes fibrosos na dieta CS, porém não foi observado efeito sobre o consumo de matéria seca. A lignina subestimou significativamente a digestibilidade. A utilização da FD Ai, FDNi e lignina-i para estimar a digestibilidade total é viável, no entanto, a FDAi e lignina-i não estimaram adequadamente as digestibilidades parciais. Houve efeito significativo na digestibilidade ruminal da FDA, com valores mais elevados para CS e semelhantes para FGM, em relação à dieta MI. A digestibilidade total da FDA foi maior na dieta CS, porém, as digestibilidades dos demais componentes não foram afetadas pelas diferentes fontes energéticas. Não houve diferença significativa para a digestibilidade da energia e nos valores obtidos de NDT, com média de $61,5 \%$. A casca de soja e o farelo de gérmen de milho, em substituição parcial do milho, mostraram-se fontes alternativas satisfatórias para a inclusão na dieta de bovinos.

Palavras-chave: casca de soja, farelo de gérmen de milho, fonte de carboidrato, indicadores internos

\section{Intake, Total and Partial Digestibility of Diets with Sunflower Meal and Three Energy Sources in Confined Steers}

\begin{abstract}
Feed intake, partial and total digestibility and nitrogen balance were evaluated in confined steers. Three crossbreed steers, rumen and duodenum cannulated, were allotted to two 3 x 3 Latin square experimental design. The experimental diets were composed by corn silage (60\%) and concentrate with sunflower meal as protein source and ground corn as energy source (MI). The ground corn was partially substituted by soybean hulls (CS) or by corn germ meal (FGM). Lignin and indigestible ADF (iADF), NDF (iNDF) and lignin (i-lignin) determined by $144 \mathrm{~h}$ of in vitro digestion were used as markers to estimate the total and partial diet digestibility of diets. The fiber intake was higher on CS diet, however no effect on dry matter intake was observed. Lignin underestimated significantly the digestibility. Indigestible ADF, iNDF and i-lignin was able to estimate total digestibility, however iADF and i-lignina did not estimate adequately the partial digestibility. Ruminal ADF digestibility was influenced by diets with higher values for CS and similar values for FGM, in relation to MI. Total ADF digestibility was higher in diet CS, but the other nutrients digestibility were not affected by different energy sources. Energy digestibility and NDT values did not differ among diets, with average of $61.5 \%$. Soybean hulls and corn germ meal, on partial substitution of ground corn, were satisfactory alternative sources for inclusion on steer diets.
\end{abstract}

Key Words: carbohydrate source, corn germ meal, internal markers, soybean hulls

\section{Introdução}

O consumo e digestibilidade dos nutrientes e a utilização destes nos diferentes compartimentos do trato digestivo é a estimativa que mais se aproxima do valor nutritivo verdadeiro dos alimentos. Segundo
Mertens (1993), o consumo de alimentos é função do animal (peso vivo, nível de produção, tamanho), do alimento (FDN efetivo, volume, capacidade de enchimento, densidade energética, necessidade de mastigação) e das condições de alimentação (disponibilidade de alimentos, espaço no cocho, tempo

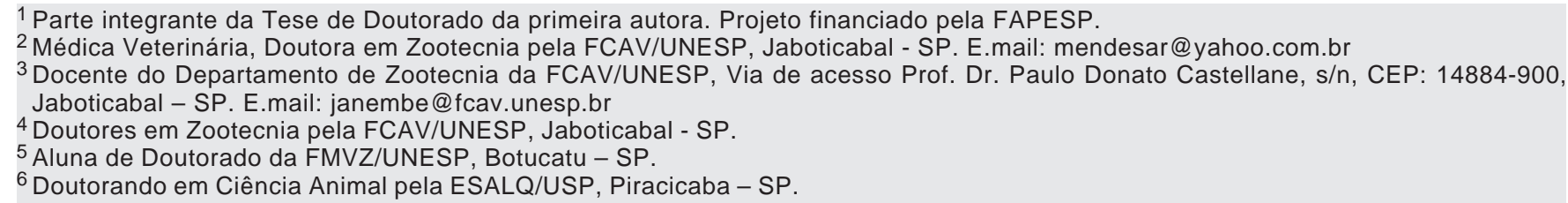


de acesso ao alimento, frequiência de alimentação). Hoover (1986), em trabalho de revisão, relatou alta correlação entre o consumo de matéria seca e o teor de FDN da forragem e de dietas com menos de 65\% de concentrado ou mais de $32 \%$ de FDN, sendo o consumo definido pelo efeito de enchimento. Entretanto Waldo (1986) ponderou que o ponto de transição entre os mecanismos reguladores de consumo nãoé fixo para uma diversidade de situações.

O coeficiente de digestibilidade de uma dieta é importante por indicar que nutrientes realmente estão disponíveis para o animal. O método convencional de determinação da digestibilidade, com coleta total de fezes, é laborioso e, em determinadas circunstâncias, inviável. Os indicadores têm-se mostrado úteis e eficientes na estimativa da digestibilidade, proporcionando resultados próximos aos obtidos pelo método de coleta total. As substâncias avaliadas como indicadores internos potenciais são os componentes da parede celular potencialmente indigestíveis. Esses indicadores internos apresentam a vantagem de já estarem presentes no alimento e, de modo geral, permanecerem uniformemente distribuídos na digesta durante o processo de digestão e excreção (Piaggio et al., 1991). Berchielli et al. (2000), ao compararem os indicadores FDA, FDN e lignina indigestíveis após 144 horas de incubação, não observaram diferença na estimativa da digestibilidade, quando comparados ao método de coleta total. Vários autores recentemente estão utilizando e avaliando os indicadores internos em busca da estimativa mais confiável de produção fecal, fluxo duodenal e digestibilidades parciais e totais (Zeoula et al., 2001, Freitas et al., 2002a).

O uso de subprodutos industriais na alimentação de bovinos é importante, haja vista sua grande disponibilidade em mercados estruturados para sua comercialização e os custos reduzidos. Todavia, a confiabilidade dos resultados de digestibilidade a partir de determinado indicador interno, é variável, principalmente em decorrência da taxa de passagem específica de cada ingrediente.

A Conab - Companhia Nacional de Armazenagem até o ano de 1996/1997, nas estatísticas de produção agrícola, não acusava a presença de girassol. No entanto, no ano seguinte, foram constatadas 15,8 mil toneladas e, nos anos de 1997/1999, 49 mil toneladas foram colhidas. Até o ano de 2001, houve crescimento de $616 \%$ (Agrianual, 2002), sobretudo na região centro-oeste, que disponibiliza o farelo de girassol oriundo da produção de óleo. Do ponto de vista nutricional, há grande variação na composição bromatológica e nos coeficientes de digestibilidade do farelo de girassol, atribuídos, principalmente, às características da semente, às formas de extração do óleo e à quantidade de casca presente no farelo. O farelo de girassol com casca disponível no Brasil, atualmente, apresenta valores de 31,4\% de proteína bruta e valores médios de FDN e FDA de 48,3 e $34,9 \%$, respectivamente (Galati et al., 2002a). Estudando a inclusão de farelo de girassol no concentrado de bezerros da raça holandesa, Garcia (2001) concluiu que não houve prejuízo na digestibilidade da matéria seca e dos nutrientes da dieta até o nível de $45 \%$ no concentrado ( $17,8 \%$ na dieta total), em substituição ao farelo de soja .

Com o objetivo de maximizar a produção de proteína microbiana, deve-se sincronizar a degradação de energia e proteína no rúmen, portanto fontes alternativas de energia devem ser avaliadas juntamente com o farelo de girassol, para buscar o melhor efeito associativo entre os alimentos. Neste sentido, Peiris et al. (1998) realizaram uma pesquisa com o propósito de avaliar o efeito da inclusão de grão de sorgo na dieta de novilhos Hereford, que receberam farelo de girassol como única fonte de proteína na ração $(19,4 \%)$, sobre a digestibilidade aparente da matéria seca, composição da carcaça, utilização de nitrogênio e concentração ruminal de ácidos graxos voláteis. Os autores observaram que as rações que continham o farelo de girassol apresentaram em média, coeficiente de digestibilidade da matéria seca de $79,1 \%$, e que a inclusão do grão de sorgo aumentou a digestibilidade das dietas em $28,7 \%$. Dessa forma, a digestibilidade do farelo de girassol possivelmente foi afetada pela composição de carboidratos dietéticos, o que contribuiu para o incremento do coeficiente de digestibilidade da dieta.

O grão de milho é a fonte energética mais utilizada nas dietas de bovinos. No entanto, pode provocar efeito associativo negativo, quando incluído em dietas mistas de volumosos e concentrados (Nakamura \& Owen, 1989), o que leva à procura de novas alternativas de ingredientes e à minimização dos custos com alimentação. Uma dessas alternativas é a utilização de subprodutos da industrialização do milho. O gérmen de milho é obtido pelo processamento por via seca e, com a extração por solvente, gera o óleo de milho e o farelo de gérmen de milho (Fernandes, 1998).

\section{R. Bras. Zootec., v.34, n.2, p.679-691, 2005}


Ferreira (2001) avaliou, em bovinos, a digestibilidade total e parcial do milho e de gérmen de milho com 10 , 7 ou $1 \%$ de extrato etéreo, extrusados ou não, e observou maior digestibilidade total da matéria seca para os gérmens, sendo que os extrusados apresentaram maiores valores de digestibilidade que os não extrusados $(75,2$ vs $69,2 \%)$.

Outra alternativa pesquisada, nos últimos anos, como fonte energética para ruminantes é a casca de soja. Seu maior benefício decorre da alta porcentagem de fibra altamente digestível, proporcionando valor energético próximo ao milho. Devido ao seu elevado teor de fibra e de NDT, a casca de soja tem sido muito utilizada como fonte energética para vacas em lactação, pois essa fibra, altamente digestível, mantém a fermentação ruminal normal e, portanto, não reduz o crescimento dos microrganismos celulolíticos, evitando problemas de acidose e mantendo teor normal de gordura no leite (Nakamura \& Owen, 1989). Gomes \& Andrade (1996), avaliando a substituição do milho pela casca de $\operatorname{soja}(0,50$ e $100 \%)$ em dietas para novilhos, não observaram diferença na digestibilidade da matéria seca, matéria orgânica e energia bruta entre as dietas, porém encontraram aumento linear na digestibilidade da FDN e FDA com a inclusão da casca de soja. No entanto, Nakamura \& Owen (1989) observaram queda linear para a digestibilidade da matéria seca em dietas para vacas alimentadas com silagem de alfafa e concentrados com 95, 50 e $0 \%$ de casca de soja, em substituição ao milho, mas sugeriram efeito associativo positivo da casca sobre a digestão da fibra nas dietas com substituição de $50 \%$ do milho pela casca.

Objetivou-se avaliar o consumo alimentar, a digestibilidade parcial e total e o balanço de nitrogênio em novilhos, alimentados com dietas contendo silagem de milho e três fontes de energia, grão de milho moído, casca do grão de soja e farelo de gérmen de milho combinados com farelo de girassol como fonte de proteína.Comparou-se quatro indicadoresinternos:FDA, FDN e lignina indigestíveis e lignina para a estimativa de produção fecal e fluxo duodenal da digesta.

\section{Material e Métodos}

O experimento foi conduzido na Unidade Animal de Estudos Digestivos e Metabólicos, do Departamento de Zootecnia da Faculdade de Ciências Agrárias e Veterinárias/Unesp, Campus de Jaboticabal, SP, no período de abril a dezembro de 2000. Foram utilizados três novilhos de corte cruzados, de aproximadamente 20 meses e $370 \mathrm{~kg}$ de peso médio inicial, providos de cânulas no rúmen e do tipo T no duodeno, distribuídos em dois delineamentos em quadrado latino, totalizando seis períodos experimentais. Os animais foram alojados embaias individuais, com piso de cimento e água à vontade. A cada três meses os animais receberam vermífugo, na dose recomendada.

A composição bromatólogica dos ingredientes utilizados na formulação das dietas encontram-se na Tabela 1.

As dietas experimentais, fornecidas duas vezes ao dia, eram constituídas de $60 \%$ de silagem de milho e $40 \%$ de concentrado, sendo que os ingredientes presentes nos concentrados foram moídos em peneira com malha de $3 \mathrm{~mm}$. As dietas foram formuladas visando a substituição parcial do milho (MI) pela casca de soja (CS) ou pelo farelo de gérmen de milho (FGM), tendo como fonte de proteína o farelo de girassol, sendo calculadas de acordo com as exigências do NRC (1996) para um ganho de 1,2 kg/dia e de forma a serem isoprotéicas (Tabela 2).

Cada período experimental consistiu em 14 dias de adaptação e quatro dias para as coletas de amostras de alimentos fornecidos, sobras, digesta duodenal e fezes. Foram retiradas amostras de $200 \mathrm{~mL}$ de digesta duodenal e $300 \mathrm{~g}$ de fezes colhidas diretamente no reto do animal, do $15^{\circ}$ ao 19 - dia, avançando em duas horas a cada dia, de tal forma que, nos quatro dias de colheita, foram obtidas amostras nos seguintes horários: 2, 4, 6, 8, 10, 12, $14,16,18,20,22$ e 24 horas. As amostras foram présecas a $55^{\circ} \mathrm{C}$ por 72 horas, moídas em peneira de 16 mesh $(1 \mathrm{~mm})$ e compostas por animal e por período.

Os alimentos fornecidos e as sobras de cada dieta foram pesadas e amostradas. A quantidade fornecida foi ajustada para que houvesse sobra de 5 a $10 \%$, que eram retiradas e quantificadas uma vez ao dia, pela manhã, sendo as amostras de silagem de milho e de sobras diárias pré-secas a $55^{\circ} \mathrm{C}$ por 72 horas. Todas as amostras foram moídas em peneira de 16 mesh (1 $\mathrm{mm})$ para determinação dos teores de matéria seca, matéria orgânica, proteína bruta (método Kjeldahl) e extrato etéreo, segundo metodologia descrita no AOAC (1995); e fibra em detergente neutro (FDN), fibra em detergente ácido (FDA), celulose e lignina, conforme métodos descritos por Silva (1990). Para determinação da porcentagem de amido, utilizou-se a metodologia de Hendrix (1993) para a extração, e ácido dinitrosalicínico (DNSA) para a leitura colorimétrica (Miller, 1959).

R. Bras. Zootec., v.34, n.2, p.679-691, 2005 
Tabela 1 - Composição química dos ingredientes utilizados nas dietas

Table 1 - Chemical composition of the ingredients used in the diets

\begin{tabular}{|c|c|c|c|c|c|}
\hline & & & $\begin{array}{l}\text { Ingredientes } \\
\text { Ingredients }\end{array}$ & & \\
\hline & $\begin{array}{l}\text { Silagem de milho } \\
\text { Corn silage }\end{array}$ & $\begin{array}{l}\text { Milho grão } \\
\text { Corn grain }\end{array}$ & $\begin{array}{l}\text { Casca de soja } \\
\text { Soybean hulls }\end{array}$ & $\begin{array}{c}\text { Farelo de gérmen de milho } \\
\text { Corn germ meal }\end{array}$ & $\begin{array}{c}\text { Farelo de girassol } \\
\text { Sunflower meal }\end{array}$ \\
\hline $\begin{array}{l}\text { Matéria seca (\%) } \\
\text { Dry matter }(\%)\end{array}$ & 32,4 & 86,9 & 88,9 & 88,0 & 89,0 \\
\hline $\begin{array}{l}\text { Matéria orgânica } \\
\text { Organic matter }\end{array}$ & 96,2 & 98,9 & $\begin{array}{c}\text { \% MS (\% DM) } \\
96,4\end{array}$ & 96,1 & 95,5 \\
\hline $\begin{array}{l}\text { Proteína bruta } \\
\text { Crude protein }\end{array}$ & 7,2 & 9,8 & 11,5 & 12,4 & 33,4 \\
\hline $\begin{array}{l}\text { FDN } \\
N D F\end{array}$ & 57,5 & 21,2 & 72,2 & 37,6 & 55,5 \\
\hline $\begin{array}{l}\text { FDA } \\
A D F\end{array}$ & 30,8 & 5,9 & 53,0 & 7,3 & 42,5 \\
\hline $\begin{array}{l}\text { Celulose } \\
\text { Cellulose }\end{array}$ & 24,8 & 3,3 & 46,0 & 5,7 & 31,0 \\
\hline $\begin{array}{l}\text { Lignina } \\
\text { Lignin }\end{array}$ & 6,0 & 2,6 & 7,0 & 1,6 & 11,5 \\
\hline $\begin{array}{l}\text { Extrato etéreo } \\
\text { Ether extract }\end{array}$ & 2,3 & 4,3 & 1,7 & 1,6 & 0,8 \\
\hline $\begin{array}{l}\text { Amido } \\
\text { Starch }\end{array}$ & 23,1 & 60,8 & 7,3 & 42,5 & 5,9 \\
\hline $\begin{array}{l}\mathrm{CNE}^{1} \\
N S C^{1}\end{array}$ & 30,3 & 64,4 & 11,5 & 45,8 & 7,2 \\
\hline $\begin{array}{l}\mathrm{EB}(\mathrm{kcal} / \mathrm{kg} \mathrm{MS})^{2} \\
G E(k c a l / k g D M)^{2}\end{array}$ & 4535,8 & 4340,5 & 4198,4 & 4352,3 & 4721,2 \\
\hline
\end{tabular}

${ }^{1}$ Carboidratos não-estruturais (CNE) = MO - PB - EE - FDN (corrigido para proteína), Sniffen et al. (1992).

2 Obtido em bomba calorimétrica (Parr, modelo 1281).

${ }^{1}$ Nonstructural carbohydrates (NSC) = OM - CP - EE - NDF (corrected for protein), Sniffen et al. (1992).

2 Obtained with calorimetric bomb (Parr, model 1281).

Os teores de FDN, FDA e lignina indigestíveis (FDNi, FDAi e lignina-i) foram quantificados após 144 horas de incubação in vitro de $0,5 \mathrm{~g}$ de amostra (Lippke et al., 1986). Utilizou-se saliva artificial e líquido ruminal na proporção de 4:1, em um único estágio de digestão, segundo o método de Tilley \& Terry (1963), citados por Silva (1990). Após a incubação, os tubos foram colocados a $5^{\circ} \mathrm{C}$ para interromper parcialmente a digestão, e os conteúdos quantitativamente transferidos para os copos de Berzelius $(600 \mathrm{~mL})$. Adicionou-se $50 \mathrm{~mL}$ de solução detergente ácida ou solução detergente neutra e procedeu-se à determinação da FDA ou FDN, conforme o método descrito por Silva (1990). A lignina-i foi estimada com a oxidação do resíduo de FDAi com permanganato de potássio.

Estimou-se a produção fecal, os fluxos duodenais e os coeficientes de digestibilidade de acordo com Schneider \& Flatt (1975). Os nutrientes digestíveis totais (NDT) foram calculados segundo Sniffen et al. (1992), utilizando-se os coeficientes de digestibilidade aparente obtidos no experimento.
A partir do coeficiente de digestibilidade da energia bruta obtiveram-se os valores de energia digestível (ED). Os valores de energia metabolizável (EM), energia líquida de mantença (Elm) e energia líquida de ganho (Elg) foram calculados, conforme recomendações de Sniffen et al. (1992), em que:

$$
\mathrm{EM}=0,82 \mathrm{ED}
$$$$
\mathrm{Elm}=-1,12+1,37 \mathrm{EM}-0,138 \mathrm{EM}^{2}+0,0105 \mathrm{EM}^{3}
$$$$
\mathrm{Elg}=-1,65+1,42 \mathrm{EM}-0,174 \mathrm{EM}^{2}+0,0122 \mathrm{EM}^{3}
$$

As amostras de urina foram obtidas durante 24 horas, segundo método descrito por Valadares et al., (1997), em cada período, dois dias após o término da colheita das amostras de digestibilidade. Utilizou-se funis emborrachados, fixos ao abdômen dos animais por meio de elásticos e acoplados a mangueiras de silicone, procedendo-se à colheita em baldes de plástico. Para que não houvesse perda de nitrogênio por volatilização, foi colocado no recipiente, antes da colheita, $50 \mathrm{~mL}$ de ácido clorídrico 1:1. Após a colheita, o volume de urina foi medido, e retirou-se uma alíquota referente a $10 \%$ do volume total. Durante as 24 horas, as fezes produzidas eram colhidas, 
Tabela 2 - Composição percentual e química das dietas experimentais

Table 2 - Percentual and chemical composition of the experimental diets

\begin{tabular}{|c|c|c|c|}
\hline \multirow[t]{2}{*}{$\begin{array}{l}\text { Ingrediente (\%) } \\
\text { Ingredient }(\%)\end{array}$} & \multicolumn{3}{|c|}{$\begin{array}{l}\text { Dieta } \\
\text { Diet }\end{array}$} \\
\hline & MI & CS & FGM \\
\hline Silagem de milho & 60,0 & 60,0 & 60,0 \\
\hline Corn silage & & & \\
\hline $\begin{array}{l}\text { Milho grão } \\
\text { Corn grain }\end{array}$ & 18,9 & 8,2 & 8,2 \\
\hline Casca de soja & - & 11,6 & - \\
\hline $\begin{array}{l}\text { Soybean hulls } \\
\text { Farelo de gérmen de milho } \\
\text { Corn germ meal }\end{array}$ & - & - & 11,6 \\
\hline $\begin{array}{l}\text { Farelo de girassol } \\
\text { Sunflower meal }\end{array}$ & 20,4 & 19,7 & 19,7 \\
\hline $\begin{array}{l}\text { Suplemento mineral } \\
\text { Mineral supplement }\end{array}$ & 0,7 & 0,7 & 0,7 \\
\hline $\begin{array}{l}\text { Composição química (\% MS) } \\
\text { Chemical composition }(\% D M)\end{array}$ & & & \\
\hline $\begin{array}{l}\text { Matéria orgânica } \\
\text { Organic matter }\end{array}$ & 95,9 & 95,8 & 95,8 \\
\hline $\begin{array}{l}\text { Proteína bruta } \\
\text { Crude protein }\end{array}$ & 13,0 & 13,1 & 13,2 \\
\hline $\begin{array}{l}\text { FDN } \\
N D F\end{array}$ & 49,8 & 55,5 & 51,5 \\
\hline $\begin{array}{l}\text { FDA } \\
A D F\end{array}$ & 28,3 & 33,5 & 28,2 \\
\hline $\begin{array}{l}\text { Celulose } \\
\text { Cellulose }\end{array}$ & 21,9 & 26,6 & 22,0 \\
\hline $\begin{array}{l}\text { Lignina } \\
\text { Lignin }\end{array}$ & 6,4 & 6,9 & 6,2 \\
\hline $\begin{array}{l}\text { Extrato etéreo } \\
\text { Ether extract }\end{array}$ & 2,2 & 1,9 & 1,9 \\
\hline $\begin{array}{l}\text { Amido } \\
\text { Starch }\end{array}$ & 26,6 & 20,9 & 24,9 \\
\hline $\begin{array}{l}\mathrm{CNE}^{1} \\
N S C^{1}\end{array}$ & 31,8 & 26,2 & 30,2 \\
\hline
\end{tabular}

$\overline{1}$ Carboidratos não-estruturais $(\mathrm{CNE})=\mathrm{MO}-\mathrm{PB}-\mathrm{EE}-\mathrm{FDN}$ (corrigido para proteína), Sniffen et al. (1992). MI = dieta formulada com milho; CS = substituição parcial do milho pela casca de soja; FGM = substituição parcial do milho pelo farelo de gérmen de milho.

${ }^{1}$ Nonstructural carbohydrates (NSC) $=O M-C P-E E-N D F$ (corrected for protein), Sniffen et al. (1992). MI = diet formulated with corn; CS = corn partial substitution for soybean hulls; FGM = corn partial substitution for corn germ meal.

pesadas e amostradas imediatamente após a defecação.

Os animais foram distribuídos em dois delineamentos em quadrado latino, em parcela subdividida para a comparação entre indicadores, sendo as dietas estudadas nas parcelas e os indicadores nas subparcelas. Os dados foram submetidos à análise de variância, e as médias comparadas pelo teste de Tukey (5\%), pelo procedimento GLM do SAS® (1995).

\section{Resultados e Discussão}

As médias de consumos ( $\mathrm{kg} / \mathrm{dia})$ de matéria seca (MS), matéria orgânica (MO), proteína bruta (PB), fibra em detergente neutro (FDN), fibra em detergente ácido (FDA), celulose, lignina, extrato etéreo (EE) e amido encontram-se na Tabela 3 .

As diferentes fontes energéticas estudadas não influenciaram o consumo de matéria seca, matéria orgânica e proteína bruta, obtendo-se médias de 9,14 ; 8,76 e $0,97 \mathrm{~kg} / \mathrm{dia}$, respectivamente. Isso correspondeu a 1,$71 ; 1,64$ e $0,18 \%$ do peso corporal médio dos animais durante o experimento, para a ingestão de matéria seca, matéria orgânica e proteína bruta.

A ingestão de FDN proporcionada pela dieta MI foi significativamente menor que o valor obtido na dieta CS, provavelmente em razão dos baixos teores

Tabela 3 - Consumo (kg/dia) de matéria seca (MS), matéria orgânica $(\mathrm{MO})$, proteína bruta $(\mathrm{PB})$, fibra em detergente neutro (FDN), fibra em detergente ácido (FDA), celulose (Cel), lignina, extrato etéreo (EE) e amido

Table 3 - Daily intake $(\mathrm{kg})$ of dry matter (DM), organic matter $(O M)$, crude protein $(C P)$, neutral detergent fiber $(N D F)$, acid detergent fiber (ADF), cellulose (Cel), lignin, ether extract (EE) and starch

\begin{tabular}{lcccc}
\hline & \multicolumn{4}{c}{$\begin{array}{c}\text { Dieta } \\
\text { Diet }\end{array}$} \\
\cline { 2 - 4 } & MI & CS & FGM & CV $(\%)$ \\
\hline $\begin{array}{l}\text { Matéria seca } \\
\text { Dry matter } \\
\text { Matéria orgânica }\end{array}$ & $9,13 \mathrm{a}$ & $9,26 \mathrm{a}$ & $9,03 \mathrm{a}$ & 6,88 \\
$\begin{array}{l}\text { Organic matter } \\
\text { Proteína bruta }\end{array}$ & $0,97 \mathrm{a}$ & $1,01 \mathrm{a}$ & $0,94 \mathrm{a}$ & 7,35 \\
$\begin{array}{l}\text { Crude protein } \\
\text { FDN }\end{array}$ & $4,29 \mathrm{~b}$ & $4,96 \mathrm{a}$ & $4,52 \mathrm{ab}$ & 7,39 \\
$\begin{array}{l}\text { NDF } \\
\text { FDA }\end{array}$ & $2,37 \mathrm{~b}$ & $3,06 \mathrm{a}$ & $2,38 \mathrm{~b}$ & 7,20 \\
$\begin{array}{l}\text { ADF } \\
\text { Celulose }\end{array}$ & $1,74 \mathrm{~b}$ & $2,46 \mathrm{a}$ & $1,73 \mathrm{~b}$ & 7,64 \\
$\begin{array}{l}\text { Cellulose } \\
\text { Lignina }\end{array}$ & $0,60 \mathrm{ab}$ & $0,61 \mathrm{a}$ & $0,53 \mathrm{~b}$ & 7,80 \\
$\begin{array}{l}\text { Lignin } \\
\text { Extrato etéreo } \\
\text { Ether extract } \\
\begin{array}{l}\text { Amido } \\
\text { Starch }\end{array}\end{array}$ & $0,28 \mathrm{a}$ & $0,24 \mathrm{~b}$ & $0,22 \mathrm{c}$ & 5,14 \\
\hline
\end{tabular}

Médias seguidas de letras diferentes na mesma linha, diferem $(\mathrm{P}<0,05)$ pelo teste de Tukey. $\mathrm{MI}=$ dieta formulada com milho; $\mathrm{CS}=$ substituição parcial do milho pela casca de soja; $\mathrm{FGM}=$ substituição parcial do milho pelo farelo de gérmen de milho. CV = coeficiente de variação.

Means followed by different letters in the row are different $(P<.05)$ by Tukey test. $M I=$ diet formulated with corn; $C S$ = corn partial substitution for soybean hulls; FGM = corn partial substitution for corn germ meal. $C V=$ coefficient of variation. 
de FDN do grão de milho, enquanto que a ingestão de FDA e de celulose da dieta contendo casca de soja em substituição parcial ao milho apresentaram valores mais elevados $(\mathrm{P}<0,05)$ de consumo.

A ingestão voluntária de matéria seca é altamente relacionada ao conteúdo de FDN do alimento e das dietas, porque a fermentação e a passagem da FDN pelo retículo-rúmen são mais lentas que outros constituintes dietéticos, tendo grande efeito no enchimento e sobre o tempo de permanência, comparado aos componentes não fibrosos do alimento (Van Soest, 1994). No entanto, apesar de o consumo de FDN da dieta contendo casca de soja ter sido significativamente mais elevado que da dieta contendo apenas milho como fonte energética, o consumo de matéria seca não diferiu estatisticamente entre as fontes. O mesmo ocorreu para o consumo de FDA que foi 29,1 e 28,6\% superior às dietas MI e FGM, respectivamente e, de celulose, 41,4 e $42,2 \%$ superior às dietas MI e FGM, respectivamente.

Vários autores também observaram que, apesar da maior ingestão de fibra em dietas com casca de soja, o consumo de matéria seca não foi afetado (Cunninghan et al., 1993; Mansfield \& Stern, 1994 e Silva et al., 1999). Essa maior ingestão de fibra na dieta CS está relacionada ao maior teor dessa fração na casca de soja, que apresenta fibra altamente digestível, e também ao seu tamanho de partícula, que pode ter favorecido a digestão e passagem pelo retículo-rúmen (MacGregor et al., 1976).
A maior ingestão de amido da dieta MI foi relacionada ao maior valor desse nutriente na dieta total (26,6\%), o que não ocorreu com a ingestão de amido na dieta FGM (24,9\% na dieta). Esse fato pode ser explicado pela maior porcentagem de amido na sobra de ração dos animais alimentados com FGM, possivelmente pela granulometria desse ingrediente, cujas pequenas partículas podem ter ficado aderidas à fibra da silagem da ração rejeitada. Dessa maneira, a ingestão de amido pela dieta FGM se assemelhou mais à dieta CS do que à dieta MI.

As variáveis utilizadas para a comparação entre os indicadores encontram-se na Tabela 4.

Oindicador utilizado influenciou significativamente $(\mathrm{P}<0,05)$ os coeficientes de digestibilidade ruminal e intestinal, sendo que a lignina subestimou significativamente a digestibilidade $(\mathrm{P}<0,05)$. Provavelmente, a metodologia utilizada para a determinação da lignina não foi a mais adequada, e as diferenças químicas e/ou físicas encontradas na lignina da digesta duodenal e das fezes podem ter subestimado esse componente nessas amostras.

Resultados similares foram encontrados por Valadares Filho et al. (1985), que observaram que as estimativas de digestibilidade total, por meio do óxido crômico ou pelo método de coleta total, foram em média 24\% superiores aos encontrados pela lignina.

Fahey \& Jung (1983) citam prováveis razões para a baixa recuperação da lignina: digestão verdadeira; digestão aparente obtida pela formação de complexos

Tabela 4 - Coeficientes de digestibilidade (CD) ruminal, intestinal e total da matéria seca, produção fecal (kg/dia) e fluxo de matéria seca duodenal ( $\mathrm{kg} / \mathrm{dia})$, estimada pelos diferentes indicadores

Table 4 - Coefficients (CD) of ruminal, intestinal and total digestibility of dry matter, faecal output (kg/day), and duodenal flow of dry matter ( $\mathrm{kg} /$ day), estimated by different markers

\begin{tabular}{|c|c|c|c|c|c|}
\hline & $\begin{array}{l}\text { FDAi } \\
i A D F\end{array}$ & $\begin{array}{l}\text { FDNi } \\
i N D F\end{array}$ & $\begin{array}{l}\text { Lignina-i } \\
\text { i-lignin }\end{array}$ & $\begin{array}{l}\text { Lignina } \\
\text { Lignin }\end{array}$ & $\mathrm{CV}(\%)$ \\
\hline $\begin{array}{l}\text { CD ruminal }(\%) \\
\text { CD ruminal }(\%)\end{array}$ & $48,34 \mathrm{a} \pm 9,06$ & $38,27 \mathrm{~b} \pm 8,27$ & $33,68 b \pm 11,36$ & $3,98 \mathrm{c} \pm 9,06$ & 25,09 \\
\hline $\begin{array}{l}\text { CD intestinal (\%) } \\
C D \text { intestinal (\%) }\end{array}$ & $15,39 \mathrm{c} \pm 7,40$ & $21,30 c \pm 6,44$ & $30,27 b \pm 8,97$ & $41,88 \mathrm{a} \pm 10,96$ & 28,03 \\
\hline $\begin{array}{l}\text { CD total }(\%) \\
C D \text { total }(\%)\end{array}$ & $63,73 \mathrm{a} \pm 5,11$ & $59,52 \mathrm{a} \pm 5,40$ & $63,94 \mathrm{a} \pm 6,03$ & $45,86 b \pm 6,67$ & 9,34 \\
\hline $\begin{array}{l}\text { Produção fecal } \\
\text { Faecaloutput }\end{array}$ & $3,32 \mathrm{~b} \pm 0,60$ & $3,72 b \pm 0,71$ & $3,30 b \quad 0,69$ & $4,93 \mathrm{a} \pm 0,64$ & 12,63 \\
\hline $\begin{array}{l}\text { Fluxo duodenal } \\
\text { Duodenal flow }\end{array}$ & $4,74 \mathrm{c} \pm 1,08$ & $5,75 b \pm 1,11$ & $6,07 b \pm 1,25$ & $8,77 \mathrm{a} \pm 1,12$ & 12,47 \\
\hline
\end{tabular}

Médias nas linhas, seguidas de letras diferentes, diferem entre si pelo teste de Tukey $(\mathrm{P}<0,05)$. MI = dieta formulada com milho; CS = substituição parcial do milho pela casca de soja; FGM = substituição parcial do milho pelo farelo de gérmen de milho. CV = coeficiente de variação.

Means followed by different letters in the row are different by Tukey test $(P<.05)$. MI = diet formulated with corn; CS = corn partial substitution for soybean hulls; FGM = corn partial substitution for corn germ meal. $\mathrm{CV}=$ coefficient of variation.

\section{R. Bras. Zootec., v.34, n.2, p.679-691, 2005}


lignina-carboidratos solúveis, que passam pelo rúmen e, provavelmente, pelo intestino, como polímeros e não são recuperados no resíduo de fibra das fezes; destruição parcial da lignina fecal pelos reagentes utilizados nos métodos analíticos; e diferenças químicas e/ou físicas entre alimentos e fezes nos materiais naturais empiricamente definidos como lignina.

Em relação aos valores estimados para a digestibilidade no trato digestório total e para produção fecal, não houve diferença significativa entre os indicadores FDNi, FDAi e lignina-i. Resultados semelhantes aos encontrados por Berchielli et al. (2000), que não observaram diferença significativa entre FDNi, FDAi e coleta total de fezes para a estimativa da digestibilidade. No entanto Ítavo et al. (2001) sugeriram que os valores de digestibilidade total foram subestimados com a utilização da FDNi. Zeoula et al. (2001), por sua vez, observaram que os valores estimados de digestibilidade total com FDNi e cinza insolúvel em ácido não diferiram aos valores da coleta total de fezes.

Para a estimativa do fluxo duodenal e conseqüente determinação das estimativas de digestibilidades parciais, houveram diferenças significativas entre os indicadores. Transformando os valores de digestibilidade ruminal em relação ao total digerido, obtêm-se os valores: 75,9; 64,3 e 52,7\%, para a FDAi, FDNi e lignina-i, respectivamente. A lignina-i possivelmente tenha subestimado a digestibilidade ruminal e superestimado o fluxo duodenal, como foi observado com mais intensidade quando se utilizou a lignina. Outro fator que contribui para que a lignina-i não seja o indicador mais adequado é o fato das amostras apresentarem baixos teores de lignina-i, levando a maiores erros durante as análises.

Valadares Filho (1995) propôs uma equação, obtida com 106 observações, associando a matéria orgânica digerida no rúmen (MODR) aos valores de matéria orgânica digerida no trato digestório total (MOD). A equação proposta foi: $\mathrm{MODR}=-0,063+$ $0,66 \mathrm{MOD}$, com R $^{2}=0,98$. Sabendo-se que a estimativa de digestibilidade total não apresentou diferença entre os indicadores, utilizou-se essa equação para estimar a MODR a partir da matéria orgânica digerida no trato digestório total obtida com utilização da FDNi e da FDAi. Comparando os resultados experimentais de MODR neste experimento e os estimados pela equação, observou-se que os valores obtidos com a FDNi foram mais próximos aos estimados, mostrando que foi o indicador mais adequado neste experimento (diferença média obtida: 0,03 kg vs 0,61 kg para FDNi e FDAi, respectivamente).

Os coeficientes de digestibilidade ruminal (préduodenal) e intestinal (pós-duodenal) da matéria seca (MS), matéria orgânica (MO), proteína bruta (PB), fibra em detergente neutro (FDN), fibra em detergente ácido (FDA), celulose, extrato etéreo (EE) e amido estimados pela FDNi encontram-se nas Tabelas 5 e 6 , respectivamente.

A digestibilidade ruminal da MS, MO, PB, FDN, EE e amido não foram influenciadas pelas diferentes fontes energéticas. No entanto, a FDA da dieta CS apresentou-se mais digestível, quando comparada à dieta MI (em relação ao total ingerido).

A média encontrada para a digestibilidade ruminal da matéria seca, 38,2\% (64,3\% do total digerido) está próxima ao encontrado por Freitas et al. (2002b), que obtiveram médias de $38,9 \%$ do total ingerido em rações com silagem de milho, cana de açúcar e concentrado com casca e raspa de mandioca ensiladas com polpa cítrica em novilhos.

Quando há sincronismo entre energia e proteína disponíveis ao crescimento microbiano no rúmen, espera-se que o valor da digestibilidade aparente ruminal da PB seja o mais próximo possível de zero. De acordo com os resultados apresentados, o valor médio de digestibilidade ruminal da PB foi de 20,97\%. Esse valor pode ser devido à alta degradação ruminal do farelo de girassol, principal fonte protéica utilizada nas dietas. Galati et al. (2002a) observaram valores de 96,7\% de degradabilidade potencial da proteína do farelo de girassol, e valores de taxa de degradação de 9,9\%/h.

Silva et al. (2002), avaliando dois níveis de casca de soja e três fontes protéicas em dietas para novilhos, obtiveram valores médios de digestibilidade da PB semelhantes aos encontrados neste experimento $(22,1 \%)$, e justificaram pelas altas taxas de degradação da proteína das fontes nitrogenadas das dietas e pela falta de sincronismo e quantidade de cetoácidos em relação à liberação de nitrogênio, necessários para o crescimento microbiano sendo, nesse caso, difundidos pela parede ruminal. Acredita-se, portanto, que os valores apresentados na Tabela 5 estejam dentro das variações encontradas na literatura.

Os maiores valores obtidos para a digestibilidade ruminal da dieta CS quando comparada à dieta MI, 11,2 e $33,8 \%$, em relação à FDN e FDA, estão de acordo aos encontrados por Nakamura \& Owen (1989), que sugeriram que a substituição parcial do milho pela casca de soja provoca efeito associativo

R. Bras. Zootec., v.34, n.2, p.679-691, 2005 
Tabela 5 - Coeficientes de digestibilidade ruminal da matéria seca (MS), matéria orgânica (MO), proteína bruta (PB), fibra em detergente neutro (FDN), fibra em detergente ácido (FDA), celulose, extrato etéreo (EE) e amido, estimados pela FDNi

Table 5 - Coefficients of ruminal digestibility of dry matter $(D M)$, organic matter $(O M)$, crude protein $(C P)$, neutral detergent fiber (NDF), acid detergent fiber $(A D F)$, cellulose, ether extract (EE) and starch, estimated by iNDF

\begin{tabular}{cccc}
\hline & \multicolumn{3}{c}{ Dieta } \\
\cline { 2 - 3 } Diet \\
MI & CS & FGM & CV $(\%)$
\end{tabular}

Digestibilidade ruminal (\% do total ingerido)

Ruminal digestibility (\% total intake)

\begin{tabular}{lcccc}
$\begin{array}{l}\text { Matéria seca } \\
\text { Dry matter }\end{array}$ & 35,94 & 38,20 & 40,54 & 16,44 \\
$\begin{array}{l}\text { Matéria orgânica } \\
\text { Organic matter }\end{array}$ & 40,92 & 43,26 & 45,31 & 13,08 \\
$\begin{array}{l}\text { Proteína bruta } \\
\text { Crude protein }\end{array}$ & 21,10 & 21,57 & 20,23 & 76,84 \\
$\begin{array}{l}\text { FDN } \\
N D F\end{array}$ & 41,40 & 46,04 & 50,95 & 11,76 \\
$\begin{array}{l}\text { FDA } \\
\text { ADF }\end{array}$ & $35,26 \mathrm{~b}$ & $47,18 \mathrm{a}$ & $39,89 \mathrm{ab}$ & 12,01 \\
$\begin{array}{l}\text { Celulose } \\
\text { Cellulose }\end{array}$ & 49,66 & 56,90 & 52,35 & 15,13 \\
$\begin{array}{l}\text { Extrato etéreo } \\
\begin{array}{l}\text { Ether extract } \\
\text { Amido }\end{array}\end{array}$ & 22,29 & 6,35 & 11,12 & 123,67 \\
$\begin{array}{l}\text { Starch } \\
\text { tarch }\end{array}$ & 43,47 & 48,36 & 50,69 & 22,69 \\
\hline
\end{tabular}

Digestibilidade ruminal (\% do total digerido)

Ruminal digestibility (\% total digested)

\begin{tabular}{lcccc}
$\begin{array}{l}\text { Matéria seca } \\
\text { Dry matter }\end{array}$ & 59,53 & 64,73 & 68,50 & 12,97 \\
$\begin{array}{l}\text { Matéria orgânica } \\
\text { Organic matter }\end{array}$ & 65,66 & 71,12 & 74,10 & 10,83 \\
$\begin{array}{l}\text { Proteína bruta } \\
\text { Crude protein }\end{array}$ & 38,95 & 39,91 & 36,29 & 60,11 \\
$\begin{array}{l}\text { FDN } \\
\text { NDF }\end{array}$ & 98,38 & 101,03 & 108,08 & 8,91 \\
$\begin{array}{l}\text { FDA } \\
\text { ADF }\end{array}$ & 93,23 & 102,86 & 105,70 & 18,56 \\
$\begin{array}{l}\text { Celulose } \\
\text { Cellulose }\end{array}$ & 118,63 & 107,06 & 125,63 & 18,51 \\
$\begin{array}{l}\text { Extrato etéreo } \\
\begin{array}{l}\text { Ether extract } \\
\text { Amido }\end{array}\end{array}$ & 26,97 & 7,62 & 13,97 & 105,83 \\
$\begin{array}{l}\text { Starch } \\
\text { Mtarch }\end{array}$ & 50,50 & 57,25 & 58,35 & 21,30 \\
\hline
\end{tabular}

Médias nas linhas, seguidas de letras diferentes, diferem $(P<0,05)$ pelo teste Tukey. MI = dieta formulada com milho; CS = substituição parcial do milho pela casca de soja; FGM = substituição parcial do milho pelo farelo de gérmen de milho. $\mathrm{CV}=$ coeficiente de variação.

Means followed by different letters in the row are different $(P<.05)$ by Tukey test. $\mathrm{MI}=$ diet formulated with corn; $C S=$ corn partial substitution for soybean hulls; FGM = corn partial substitution for corn germ meal. $C V=$ coefficient of variation
Tabela 6 - Coeficientes de digestibilidade intestinal da matéria seca (MS), matéria orgânica (MO), proteína bruta (PB), fibra em detergente neutro (FDN), fibra em detergente ácido (FDA), celulose, extrato etéreo (EE) e amido, estimados pela FDNi

Table 6 - Coefficients of intestinal digestibility of dry matter $(D M)$, organic matter $(O M)$, crude protein $(C P)$, neutral detergent fiber (NDF), acid detergent fiber $(A D F)$, cellulose, ether extract (EE) and starch, estimated by iNDF

\begin{tabular}{llll}
\hline & \multicolumn{3}{c}{ Dieta } \\
\cline { 2 - 3 } Diet \\
\cline { 2 - 4 } MI & CS & FGM & \\
\hline
\end{tabular}

Digestibilidade ruminal (\% do total ingerido) Ruminal digestibility (\% total intake)

\begin{tabular}{|c|c|c|c|c|}
\hline $\begin{array}{l}\text { Matéria seca } \\
\text { Dry matter }\end{array}$ & 24,42 & 20,81 & 18,65 & 23,20 \\
\hline $\begin{array}{l}\text { Matéria orgânica } \\
\text { Organic matter }\end{array}$ & 21,40 & 17,56 & 15,85 & 24,17 \\
\hline $\begin{array}{l}\text { Organic matter } \\
\text { Proteína bruta } \\
\text { Crude protein }\end{array}$ & 33,07 & 32,47 & 35,51 & 34,97 \\
\hline FDN & 0,69 & $(-) 0,47$ & (-) 3,81 & 334,46 \\
\hline $\begin{array}{l}N D F \\
\text { FDA }\end{array}$ & 2,56 & (-) 1,31 & (-) 2,15 & 125,15 \\
\hline $\begin{array}{l}A D F \\
\text { Celulose }\end{array}$ & (-) 7,79 & (-) 3,75 & $(-) 10,68$ & (-) 115,48 \\
\hline $\begin{array}{l}\text { Cellulose } \\
\text { Extrato etéreo }\end{array}$ & 60,37 & 76,95 & 60,34 & 19,04 \\
\hline $\begin{array}{l}\text { Ether extract } \\
\text { Amido } \\
\text { Starch }\end{array}$ & 42,62 & 36,10 & 36,18 & 6. \\
\hline
\end{tabular}

Digestibilidade ruminal (\% do total digerido)

Ruminal digestibility (\% total digested)

\begin{tabular}{|c|c|c|c|c|}
\hline $\begin{array}{l}\text { Matéria seca } \\
\text { Dry matter }\end{array}$ & 40,47 & 35,27 & 31,50 & 23,04 \\
\hline Matéria orgânica & 34,34 & 28,88 & 25,90 & 25,67 \\
\hline $\begin{array}{l}\text { Organic matter } \\
\text { Proteína bruta }\end{array}$ & 61,05 & 60,09 & 63,71 & 36,64 \\
\hline $\begin{array}{l}\text { Crude protein } \\
\text { FDN }\end{array}$ & 1,62 & (-) 1,03 & (-) 8,08 & (-) 469,14 \\
\hline $\begin{array}{l}N D F \\
\text { FDA }\end{array}$ & 6,77 & $(-) 2,86$ & (-) 5,70 & 684,48 \\
\hline $\begin{array}{l}A D F \\
\text { Celulose }\end{array}$ & (-) 18,63 & (-) 7,06 & (-) 25,63 & (-)105,17 \\
\hline $\begin{array}{l}\text { Cellulose } \\
\text { Extrato etéreo }\end{array}$ & 73,03 & 92,38 & 86,03 & 20,33 \\
\hline $\begin{array}{l}\text { Amido } \\
\text { Starch }\end{array}$ & 49,50 & 42,75 & 41,65 & 26 , \\
\hline
\end{tabular}

Médias nas linhas, seguidas de letras diferentes, diferem $(P<0,05)$ pelo teste Tukey. $\mathrm{MI}=$ dieta formulada com milho; $\mathrm{CS}=$ substituição parcial do milho pela casca de soja; FGM = substituição parcial do milho pelo farelo de gérmen de milho. $\mathrm{CV}=$ coeficiente de variação.

Means followed by different letters in the row are different $(P<.05)$ by Tukey test. $\mathrm{MI}=$ diet formulated with corn; $C S=$ corn partial substitution for soybean hulls; FGM = corn partial substitution for corn germ meal. $\mathrm{CV}=$ coefficient of variation. 
sobre a digestibilidade da fibra da dieta. Tal fato também foi relatado por Grigsby et al. (1993), que observaram maior valor da digestibilidade da FDN, quando $66 \%$ do milho do concentrado foi substituído pela casca de soja.

A dieta FGM mostrou resultados 23,1 e $13,3 \%$ numericamente maiores para digestibilidade ruminal da FDN e FDA, respectivamente, em relação à dieta MI. Segundo revisão elaborada por Hoover (1986), vários fatores podem diminuir a degradação ruminal da fibra, porém o mecanismo envolvido ainda não está elucidado. De acordo com os dados revisados, o pH ruminal abaixo de 6,0 diminui a digestão da fibra, e a concentração média de amônia requerida para otimizar a digestão da fibra é maior que a concentração necessária para otimizar o crescimento microbiano, com médias de 8,0 e 3,3 mg/dL, respectivamente. Galati et al. (2002b), utilizando as mesmas dietas deste experimento, não observaram diferença entre os valores de $\mathrm{pH}$ e nitrogênio amoniacal no rúmen, com médias de 6,7 e 26,1 mg de $\mathrm{N}-\mathrm{NH}_{3} / 100 \mathrm{~mL}$ de líquido ruminal, indicando que não foram esses fatores que minimizaram a digestão ruminal da fibra na dieta MI.

Não houve diferença significativa entre os valores de digestibilidade ruminal do amido, no entanto as dietas CS e FGM apresentaram valores 11,2 e 16,6\% maiores quando comparadas à dieta MI. Zeoula \& Caldas Neto (2001) relataram em revisão que os valores de digestibilidade ruminal média do amido de dietas que apresentam o milho como fonte principal é de $50,4 \% \pm 3,6$ em relação ao total ingerido. Esses valores são mais elevados que a média encontrada na dieta MI (43,5\%).

Os processamentos pela moagem ou pela aplicação de calor, umidade e pressão, nos grãos de cereais, aumentam a susceptibilidade do amido à digestão, pela ruptura da proteína matriz ao redor dos grânulos de amido e pela gelatinização do amido, que causa o rompimento da estrutura cristalina. Essa alteração na estrutura dos grãos aumenta a digestão amilolítica pela ação das enzimas microbiana e pancreática (Nocek \& Tamminga, 1991). Isso pode justificar o valor numericamente mais elevado da digestibilidade do amido da dieta FGM (16,6\% mais elevado em relação à MI), que é peletizada durante o processo de industrialização e apresenta tamanho de partícula muito pequeno.

As digestibilidades intestinais estimadas, em relação ao ingerido ou ao total digerido, não apresen- taram diferença significativa entre as diferentes dietas (Tabela 6). A digestibilidade intestinal da PB foi, em média, $61,6 \%$ do total digerido, valor próximo ao relatado pelo NRC (1996) para a digestibilidade aparente do nitrogênio não amoniacal (65\%).

Os valores negativos obtidos para a digestibilidade da FDN, FDA e celulose das dietas indicam ausência de digestão da fração fibrosa nesse compartimento. Valores negativos para a digestibilidade intestinal da fibra são relativamente comuns (Fregadolli, 2000; Tibo et al., 2000; Freitas et al., 2002b), estando, geralmente, associados a problemas na estimativa de fluxo duodenal de matéria seca.

A média dos valores da digestibilidade intestinal do EE (83,8\% do total digerido) está de acordo as encontradas na literatura. Tibo et al. (2000) avaliando níveis de concentrado sobre a digestibilidade em bovinos F1 Nelore x Simental, obtiveram efeito linear crescente da digestibilidade intestinal do EE, com média de $79,7 \%$ no nível de $50 \%$ de concentrado. No entanto Ítavo et al. (2002) encontraram valores mais elevados, com média de $93,9 \%$ do total digerido em dietas com $40 \%$ de concentrado em bovinos.

Com relação à partição da digestão no retículorúmen e intestinos, observa-se que, apesar de não apresentar diferença significativa, houve tendência de maior digestão ruminal na dieta FGM, quando comparada à MI $(15,0$ e $12,9 \%$ mais elevados para a digestibilidade ruminal da MS e MO, respectivamente). Isso pode indicar que o farelo de gérmen de milho associado a fontes protéicas de alta degradabilidade, como o farelo de girassol, apresentam excelente potencial para maximizar a fermentação ruminal.

Os coeficientes de digestibilidade aparente total da MS, MO, PB, FDN, FDA, celulose, extrato etéreo (EE) e amido estimados pela FDNi encontram-se na Tabela 7.

As digestibilidades aparentes totais da MS e MO não apresentaram diferenças significativas entre as dietas, indicando que o maior valor da digestibilidade intestinal, na dieta, MI compensou o maior fluxo de material não digerido no rúmen para o duodeno, e as médias foram de 59,5 e 61,4\% para digestibilidade total da MS e MO, respectivamente.

Garcia (2001), avaliando a digestibilidade em dietas de bezerros holandeses alimentados com $60 \%$ de silagem de milho e quatro níveis de substituição do farelo de soja pelo farelo de girassol $(0,15,30 \%$ e $45 \%$ nos concentrados ou $0 \% ; 6,1 ; 12,1$ e $17,8 \%$ na dieta), não encontraram diferença significativa entre

R. Bras. Zootec., v.34, n.2, p.679-691, 2005 
Tabela 7 - Coeficientes de digestibilidade aparente total da matéria seca (MS), matéria orgânica (MO), proteína bruta (PB), fibra em detergente neutro (FDN), fibra em detergente ácido (FDA), celulose, extrato etéreo (EE) e amido, estimados pela FDNi

Table 7 - Coefficients of total apparent digestibility of dry matter (DM), organic matter (OM), crude protein $(C P)$, neutral detergent fiber (NDF), acid detergent fiber (ADF), cellulose, ether extract (EE) and starch, estimated by iNDF

\begin{tabular}{lccc}
\hline & \multicolumn{3}{c}{ Dieta } \\
Diet \\
\cline { 2 - 3 } MI & CS & FGM & CV $(\%)$ \\
\hline
\end{tabular}

Digestibilidade aparente total (\%)

Total apparent digestibility (\%)

$\begin{array}{lcccc}\begin{array}{l}\text { Matéria seca } \\ \text { Dry matter }\end{array} & 60,37 \mathrm{a} & 59,01 \mathrm{a} & 59,18 \mathrm{a} & 6,03 \\ \begin{array}{l}\text { Matéria orgânica } \\ \begin{array}{l}\text { Organic matter } \\ \text { Proteína bruta }\end{array}\end{array} & 62,32 \mathrm{a} & 60,83 \mathrm{a} & 61,15 \mathrm{a} & 5,15 \\ \begin{array}{l}\text { Crude protein } \\ \text { FDN }\end{array} & 42,08 \mathrm{a} & 45,57 \mathrm{a} & 47,14 \mathrm{a} & 6,53 \\ \text { NDF } & 57,82 \mathrm{~b} & 45,87 \mathrm{a} & 37,74 \mathrm{~b} & 4,23 \\ \begin{array}{l}\text { FDA } \\ \text { ADF }\end{array} & 41,86 \mathrm{~b} & 53,15 \mathrm{a} & 41,67 \mathrm{~b} & 3,61 \\ \begin{array}{l}\text { Celulose } \\ \text { Cellulose }\end{array} & 82,65 \mathrm{a} & 83,29 \mathrm{a} & 79,61 \mathrm{a} & 8,42 \\ \begin{array}{l}\text { Extrato etéreo } \\ \text { Ether extract }\end{array} & 86,08 \mathrm{a} & 84,47 \mathrm{a} & 86,87 \mathrm{a} & 1,42 \\ \begin{array}{l}\text { Amido } \\ \text { Starch }\end{array} & & & & 12,25 \\ \end{array}$

Médias nas colunas, seguidas de letras diferentes, diferem $(\mathrm{P}<0,05)$ entre si pelo teste Tukey. $\mathrm{MI}=$ dieta formulada com milho; CS = substituição parcial do milho pela casca de soja; FGM = substituição parcial do milho pelo farelo de gérmen de milho. CV = coeficiente de variação.

Means followed by different letters in the column are different $(P<.05)$ by Tukey test. $\mathrm{MI}=$ diet formulated with corn; $C S=$ corn partial substitution for soybean hulls; FGM = corn partial substitution for corn germ meal. $C V=$ coefficient of variation.

tratamentos, apresentando média de $68,5 \%$ de digestibilidade da MS. Moraes et al. (2002) e Freitas et al. (2002b), avaliando a digestibilidade da MS de dietas contendo silagem de milho e concentrado em novilhos, também obtiveram resultados mais elevados 70,0 e $65,1 \%$, respectivamente.

As diferentes fontes energéticas não influenciaram a digestibilidade total da $\mathrm{PB}, \mathrm{FDN}$ e EE, apresentando valores médios de 54,7; 44,9 e 81,9\%. As médias de digestibilidade da PB e da FDN são inferiores às relatadas por Silva et al. (2001) que, avaliando a digestibilidade de dietas com silagem de milho com e sem inoculante e $37 \%$ de concentrado, obtiveram médias de 62,7 e $53,5 \%$ para digestibilidade da PB e FDN, respectivamente. Os valores inferiores de digestibilidade da FDN podem estar relacionados à maior quantidade de fibra do concentrado utilizado neste experimento, em que grande parte é proveniente do farelo de girassol, que apresenta teor de lignina elevado (11,5\%), e baixos valores de degradabilidade da FDN (19,6\% de degradabilidade efetiva com kd de 5\%/h), segundo Galati et al. (2002a).

A digestibilidade total da FDN da dieta FGM foi $12,0 \%$ maior que a dieta MI, possivelmente influenciada pelo valor numericamente mais elevado da digestibilidade ruminal obtida nesta dieta $(50,9$ vs $41,4 \%$ ), indicando efeito associativo sobre a digestão da FDN no rúmen. Tal fato também foi observado para a digestibilidade da FDA da dieta CS, em que a digestibilidade ruminal mais elevada influenciou a digestibilidade total, mostrando valores $21,4 \%$ maiores que a média das demais dietas. Resultados explicados pela fibra altamente digestível da casca de soja e, possivelmente, pelo menor efeito associativo negativo desta fonte sobre a digestão da FDA da dieta.

A média da digestibilidade total do amido $(85,8 \%)$, obtida neste experimento, está dentro da amplitude de variação apontada por Zeoula \& Caldas Neto (2001), que apresentaram valores de 90,0\% $\pm 8,7$ para digestibilidade total de dietas com milho moído como fonte principal de amido no concentrado.

O consumo, os coeficientes de digestibilidade aparente total (CD total), da digestão ruminal (CD ruminal) e intestinal (CD intestinal), da energia bruta (EB) e os valores energéticos das dietas experimentais estão descritos na Tabela 8.

Os valores estimados de consumo e digestibilidade da energia bruta não diferiram $(P>0,05)$ entre as dietas experimentais, mas observa-se que os valores obtidos para a digestibilidade ruminal (\% digerido) na dieta MI foram 14,8 e 17,3\% numericamente inferiores em relação às dietas CS e FGM, respectivamente. Essas diferenças foram superiores às encontradas para a digestibilidade ruminal da MO, que apresentaram valores 8,3 e $12,9 \%$ menores para a dieta MI, quando comparadas às dietas CS e FGM, respectivamente.

As médias obtidas de digestibilidade ruminal da EB (35,0 e 58,0\% em relação ao total ingerido e digerido, respectivamente) foram próximas às observadas por Fregadolli (2000), que, avaliando duas fontes de energia combinadas com duas fontes de proteína, em novilhos, não encontrou efeito significativo para fontes de energia, com média de $34,5 \%$ do total ingerido e $56,8 \%$ do total digerido. No entanto,

\section{R. Bras. Zootec., v.34, n.2, p.679-691, 2005}


Tabela 8 - Consumo de energia bruta (EB), coeficientes de digestibilidade aparente (CD total), digestibilidade ruminal (CD ruminal) e digestibilidade intestinal (CD intestinal) da $E B$ e os valores energéticos das dietas experimentais

Table 8 - Gross energy (GE) intake, coefficients of apparent digestibility (total $C D$ ), ruminal digestibility (ruminal $C D$ ) and intestinal digestibility (intestinal $C D$ ) for $G E$, and energy values of the experimental diets

\begin{tabular}{|c|c|c|c|c|}
\hline & & $\begin{array}{l}\text { Dieta } \\
\text { Diet }\end{array}$ & & \\
\hline & MI & $\mathrm{CS}$ & FGM & $\mathrm{CV}(\%)$ \\
\hline $\begin{array}{l}\text { Consumo de EB } \\
\text { (Mcal/dia) }\end{array}$ & 39,96 & 41,32 & 38,41 & 6,79 \\
\hline $\begin{array}{l}\text { GE intake (Mcal/day) } \\
\text { CD total }(\%) \\
\text { Total CD }(\%)\end{array}$ & 60,12 & 60,19 & 58,69 & 5,73 \\
\hline $\begin{array}{l}\text { CD ruminal } \\
\text { (\% ingerido })\end{array}$ & 31,98 & 36,65 & 36,29 & 17,88 \\
\hline $\begin{array}{l}\text { Ruminal CD (\% intake) } \\
\text { CD ruminal } \\
\text { (\% digerido) }\end{array}$ & 52,46 & 60,21 & 61,54 & 17,60 \\
\hline $\begin{array}{l}\text { Ruminal CD (\% digested) } \\
\text { CD intestinal } \\
\text { (\% ingerido) }\end{array}$ & 28,14 & 23,55 & 22,40 & 26,02 \\
\hline $\begin{array}{l}\text { Intestinal } C D(\% \text { intake }) \\
\text { CD intestinal } \\
\text { (\% digerido })\end{array}$ & 47,54 & 39,79 & 38,46 & 24,37 \\
\hline $\begin{array}{l}\text { Intestinal CD (\% digested }) \\
\operatorname{NDT}(\%)\end{array}$ & 62,93 & 60,71 & 60,87 & 5,19 \\
\hline $\begin{array}{l}\operatorname{TDN}(\%) \\
\operatorname{ED}(\mathrm{Mcal} / \mathrm{kg})^{1}\end{array}$ & 2,65 & 2,69 & 2,52 & - \\
\hline $\begin{array}{l}D E(\text { Mcal } / \mathrm{kg})^{1} \\
\mathrm{EM}(\mathrm{Mcal} / \mathrm{kg})^{1} \\
M E(\text { Mcal } / \mathrm{kg})^{1}\end{array}$ & 2,17 & 2,21 & 2,06 & - \\
\hline $\begin{array}{l}\operatorname{Elm}(\mathrm{Mcal} / \mathrm{kg})^{1} \\
N E m(\text { Mcal } / \mathrm{kg})^{1}\end{array}$ & 1,31 & 1,34 & 1,21 & - \\
\hline $\begin{array}{l}\operatorname{Elg}(\mathrm{Mcal} / \mathrm{kg})^{1} \\
N E g(\text { Mcal } / \mathrm{kg})^{1}\end{array}$ & 0,76 & 0,79 & 0,66 & - \\
\hline
\end{tabular}

Médias nas linhas não diferem entre si pelo teste Tukey $(P<0,05)$. ${ }^{1}$ Médias não analisadas estatisticamente.

$\mathrm{MI}=$ dieta formulada com milho; $\mathrm{CS}=$ substituição parcial do milho pela casca de soja; FGM = substituição parcial do milho pelo farelo de gérmen de milho. CV = coeficiente de variação.

Means within a row do not differ $(P>.05)$ by Tukey test.

${ }^{1}$ Means do not statistically analyzed.

$M I=$ diet formulated with corn; $C S=$ corn partial substitution for soybean hulls; FGM = corn partial substitution for corn germ meal. $\mathrm{CV}=$ coefficient of variation.

esses resultados discordam daqueles observados por Caldas Neto et al. (2000), que observaram valor médio de digestibilidade ruminal da EB de 71,6\% do total digerido em bovinos alimentados com silagem de milho e concentrados com milho e resíduos de mandioca.

Os valores estimados de NDT das dietas não foram influenciados $(\mathrm{P}>0,05)$ pelas diferentes fontes energéticas, apresentado média $61,5 \%$ de NDT. Esse valor foi inferior ao relatado por Caldas Neto et al. (2000) que, avaliando diferentes fontes energéticas obtiveram valor médio de $65,6 \%$ de NDT, no entanto foram maiores que a média de $56,0 \%$ observada por Fregadolli (2000).

Os valores de energia digestível (ED), energia metabolizável (EM), energia líquida de mantença (Elm) e energia líquida de ganho (Elg) foram obtidos a partir do coeficiente de digestibilidade total da energia bruta das dietas experimentais.

Os valores médios estimados de $\operatorname{Elm}(2,15 \mathrm{Mcal} / \mathrm{kg})$ e Elg $(0,74 \mathrm{Mcal} / \mathrm{kg})$ das dietas experimentais são superiores às exigências energéticas para um ganho de $1,2 \mathrm{~kg} /$ dia de animais de $533 \mathrm{~kg}$ de média, segundo NRC (1996). As proporções proteína:energia digestíveis foram muito semelhantes para as dietas MI e CS (3,50 e 3,51 g de nitrogênio digestível/kcal ED), mas houve tendência de aumento com a dieta FGM (3,72 g N/kcal de ED).

Os valores determinados no balanço de nitrogênio dos animais alimentados com as diferentes dietas estão apresentados na Tabela 9.

Não houve diferenças para quantidade de nitrogênio ingerido, excretado, absorvido e retido entre as dietas experimentais. No entanto, foram observados valores $15,7 \%$ maiores de nitrogênio retido para a dieta FGM, em relação à média das demais

Tabela 9 - Valores obtidos no balanço de nitrogênio (N) nas dietas experimentais

Table 9 - Values obtained on nitrogen $(N)$ balance of the experimental diets

\begin{tabular}{lcccr}
\hline & \multicolumn{3}{c}{$\begin{array}{c}\text { Dieta } \\
\text { Diet }\end{array}$} & \\
\cline { 2 - 4 } & MI & CS & FGM & CV (\%) \\
\hline $\begin{array}{l}\text { N ingerido, g/dia } \\
N \text { intake, g/day }\end{array}$ & 152,71 & 160,20 & 146,59 & 9,32 \\
N fecal, g/dia & 54,86 & 56,94 & 54,49 & 7,26 \\
$N$ faecal, g/day & & & & \\
N absorvido, g/dia & 97,85 & 103,26 & 92,10 & 13,97 \\
$N$ absorbed, g/day & & & & \\
$\begin{array}{l}\text { N urina, g/dia } \\
N \text { urine, g/day }\end{array}$ & 58,23 & 65,99 & 46,47 & 18,34 \\
N retido, g/dia & 39,62 & 37,27 & 45,63 & 23,39 \\
$N$ retention, g/day & & & & \\
\hline
\end{tabular}

Médias nas linhas não diferem $(P<0,05)$ pelo teste Tukey. $\mathrm{MI}=$ dieta formulada com milho; $\mathrm{CS}$ = substituição parcial do milho pela casca de soja; FGM = substituição parcial do milho pelo farelo de gérmen de milho. $\mathrm{CV}=$ coeficiente de variação.

Means within a row do not differ $(P>.05)$ by Tukey test.

$M I=$ diet formulated with corn; $C S=$ corn partial substitution for soybean hulls; FGM = corn partial substitution for corn germ meal. $C V=$ coefficient of variation. 
dietas. A menor excreção de nitrogênio pela urina é o principal fator que levou à maior retenção de nitrogênio na dieta FGM. Uma hipótese para esse fato seria o melhor aproveitamento de $\mathrm{N}-\mathrm{NH}_{3}$ ruminal por parte dos microrganismos ruminais, havendo sincronismo de degradação de proteína e energia no rúmen, como foi relatado pelo maior valor obtido na relação nitrogênio digestível:ED (3,72 vs 3,50 g de N/kcal de ED, nas dietas FGM e MI, respectivamente). Com maior sincronismo entre energia e proteína degradada no rúmen, possivelmente haja aumento na eficiência de produção microbiana e, conseqüentemente, melhor desempenho.

\section{Conclusões}

A casca de soja e o farelo de gérmen de milho, em substituição parcial do milho não influenciaram o consumo e a digestibilidade das dietas, mostrando-se fontes alternativas satisfatórias para a inclusão na dieta de bovinos.

A maior quantidade de fibras da dieta com casca de soja não afetou o consumo, possivelmente pela sua maior digestibilidade da FDA. O farelo de gérmen de milho apresenta bom potencial para maximizar a digestão ruminal, quando associado ao farelo de girassol.

Neste experimento, a FDNi obtida in vitro foi o indicador mais adequado para estimar as digestibilidades parciais e totais das dietas.

\section{Agradecimento}

À Caramuru Alimentos Ltda, pela doação dos ingredientes: farelo de girassol, casca de soja e farelo de gérmen de milho.

\section{Literatura Citada}

AGRIANUAL 2002. Anuário da Agricultura Brasileira, São Paulo:FNP - Consultoria e Comércio, 2002. 536 p.

ASSOCIATION OF OFFICIAL ANALYTICAL CHEMISTS AOAC. Official methods of analysis. 16.ed. Washington, D.C.: $1995.1025 p$.

BERCHIELLI, T.T.; ANDRADE, P.; FURLAN, C.L. Avaliação de indicadores internos em ensaios de digestibilidade. Revista Brasileira de Zootecnia, v.29, n.3, p.830-833, 2000.

CALDAS NETO, S.F.; ZEOULA, L.M.; BRANCO, A.F. et al. Mandioca e resíduos das farinheiras na alimentação de ruminantes: digestibilidade total e parcial. Revista Brasileira de Zootecnia, v.29, n.6, p.2099-2108, 2000 (Suplemento 1).

CUNNINGHAM, K.D.; CECAVA, M.J.; JOHNSON, T.R. Nutrient digestion, nitrogen, amino acid flows in lactating cows fed soybean hulls in place of forage or concentrate. Journal of Dairy Science, v.76, n.11, p.3523-3535, 1993.

FAHEY, G.C.; JUNG, H.G. Lignin as a marker in digestion studies: a review. Journal of Animal Science, v.57, n.1, p.220-225, 1983.

FERNANDES, V.G. Subprodutos na industrialização do milho. Mogi Guaçu: Corn Products do Brasil, 1998. Não paginado. Apostila.

FERREIRA, R.N. Degradação ruminal e digestibilidades intestinal e total da proteína do milho e dos gérmens de milho. Jaboticabal: Faculdade de Ciências Agrárias e Veterinárias, 2001. 113 p. Tese (Doutorado em Zootecnia) Faculdade de Ciências Agrárias e Veterinárias. Universidade Estadual Paulista, 2001.

FREGADOLLI, F.L. Efeitos da degradabilidade ruminal do amido e do nitrigênio da dieta sobre o metabolismo ruminal e a digestibilidade em bovinos. Maringá: Universidade Estadual de Maringá, 2000. 68p. Dissertação (Mestrado em Zootecnia)- Universidade Estadual de Maringá, 2000.

FREITAS, D.; BERCHIELLI, T.T.; SILVEIRA, R.N. et al. Produção fecal e fluxo duodenal de matéria seca e matéria orgânica estimados por meio de indicadores. Revista Brasileira de Zootecnia, v.31, n.3, p.1521-1530, 2002a (Suplemento).

FREITAS, D.; BERCHIELLI, T.T.; SILVEIRA, R.N. et al. Consumo e digestibilidade aparente total e parcial de rações com cana de açúcar, casca e raspa de mandioca ensiladas com polpa cítrica. Revista Brasileira de Zootecnia, v.31, n.3, p.1531-1542, 2002b (Suplemento).

GALATI, R.L.; EZEQUIEL, J.M.B; MENDES, A.R. et al. Cinética da digestão ruminal in situ do farelo de girassol utilizado em dietas para bovinos. In: REUNIÃO ANUAL DA SOCIEDADE BRASILEIRA DE ZOOTECNIA, 39., 2002, Recife. Anais...Recife: Technomedia, 2002a. CD-ROM. Nutrição de Ruminantes.

GALATI, R.L.; EZEQUIEL, J.M.B; MENDES, A.R. et al. Influência de diferentes fontes energéticas sobre os valores de $\mathrm{pH}$ e concentrações ruminais de nitrogênio amoniacal no rúmen e no intestino. In: REUNIÃO ANUAL DA SOCIEDADE BRASILEIRA DE ZOOTECNIA, 39., 2002, Recife. Anais... Recife: Technomedia, 2002b. CD-ROM. Nutrição de Ruminantes.

GARCIA, J.A. Farelo de girassol na alimentação de bovinos leiteiros em fase de crescimento. Jaboticabal: Faculdade de Ciências Agrárias e Veterinárias, 2001. 57p. Tese (Doutorado em Zootecnia) - Faculdade de Ciências Agrárias e Veterinárias. Universidade Estadual Paulista, 2001.

GOMES, I. P.O.; ANDRADE, P. Níveis de substituição de milho por casca do grão de soja na dieta de bovinos. I. Desempenho em confinamento. In: REUNIÃO ANUAL DA SOCIEDADE BRASILEIRA DE ZOOTECNIA, 33., 1996, Fortaleza. Anais... Fortaleza: Sociedade Brasileira de Zootecnia, 1996. p.55-57.

GRIGSBY, K.N.; KERLEY, M.S.; PATERSON, J.A. et al. Combinations of starch and digestible fiber in supplements for steers consuming a low- quality bromegrass hay diet. Journal of Animal Science, v.71, n.4, p.1057-1064, 1993.

HENDRIX, D. L. Rapid extraction and analysis of nonstructural carbohydrates in plant tissues. Crop Science, v.33, n.6, p.1306-1311,1993.

HOOVER, W.H. Chemical factors involved in ruminal fiber digestion. Journal of Dairy Science, v.69, n.6, p.2755-2766, 1986.

R. Bras. Zootec., v.34, n.2, p.679-691, 2005 
ÍTAVO, L.C.V.; SILVA, F.F.; VALADARES FILHO, S.C. et al. Indicadores internos para estimativas de produção fecal e digestibilidade de nutrientes em bovinos. In: REUNIÃO ANUAL DA SOCIEDADE BRASILEIRA DEZOOTECNIA, 38., 2001, Piracicaba. Anais... Piracicaba: Sonopress, 2001. CD-ROM. Áreas técnicas: Nutrição de Ruminantes.

ÍTAVO, L.C.V.; VALADARES FILHO, S.C.; SILVA, F.F. et al. Consumo e digestibilidades aparentes totais e parciais de nutrientes em novilhos alimentados com dietas contendo vários níveis de concentrado. Revista Brasileira de Zootecnia, v.31, n.3, p.1543-1551, 2002 (Suplemento).

LIPPKE, H.; ELLIS, W.C.; JACOBS, B.F. Recovery of indigestible fiber from feces of sheep and cattle on forage diets. Journal of Dairy Science, v.69, n.2, p.403-412, 1986.

MANSFIELD, H.R.; STERN, M.D. Effects off soybean hulls and lignosulfonate-treated soybean meal on ruminal fermentation in lactating dairy cows. Journal of Dairy Science, v.77, n.4, p.1070-1083, 1994.

MacGREGOR, C.A.; OWEN, F.G.; McGILL, L.D. Effect of increasing ration fiber with soybean mill run on digestibility and lactation performance. Journal of Dairy Science, v.59, n.4, p.682-689, 1976.

MERTENS, D.R. Rate and extent of digestion. In: FORBES, J.M.; FRANCE, J. (Eds.) Quantitative aspects of ruminant digestion and metabolism. 2.ed. Wallingford: $C A B$ International, 1993. p.13-51.

MILLER, G.L. Use of dinitrosalicylic acid reagent for determination of reducing sugar. Analytical Chemistry, v.31, n.3, p.426-428, 1959.

MORAES, S.A.; PEREIRA, O.G.; GARCIA, R. et al. Consumo e digestibilidade aparente de nutrientes, em bovinos recebendo dietas contendo silagem de milho e concentrado em diferentes proporções. In: REUNIÃO ANUAL DA SOCIEDADE BRASILEIRA DE ZOOTECNIA, 39., 2002, Recife. Anais... Recife:Technomedia, 2002. CD-ROM.

NAKAMURA, T.; OWEN, F.G. High amounts of soyhulls for pelleted concentrate diets Journal of Dairy Science, v.72, n.4, p.988-994, 1989.

NATIONAL RESEARCH COUNCIL - NRC. Nutrient requirements of beef cattle. 7.ed. Washington, D.C.: National Academic Press, 1996. 242p.

NOCEK, J.E.; TAMMINGA, S. Site of digestion of starch in the gastrointestinal tract of dairy cows and its effect on milk and composition. Journal of Dairy Science, v.74, n.10, p.3598-3605, 1991.

PEIRIS, H.; ELLIOTT, R.; NORTON, B.W. Substitution of sorghum grain for molasses increases the live weight grain of steers given molasses-based diets. Journal of Agricultural Science, v.130, n.2, p.199-204, 1998.

PIAGGIO, L.M.; PRATES, E.R.; PIRES, F.F. et al. Avaliação das cinzas insolúveis em ácido, fibra em detergente ácido indigestível e lignina em detergente ácido indigestível como indicadores internos da digestibilidade. Revista da Sociedade Brasileira de Zootecnia, v.20, n.3, p.306-312, 1991.

STATISTICAL ANALYSES SYSTEMS - SAS. Language Guide v.6, 3.ed. Cary: 1995. 530p.

SCHNEIDER, B.H.; FLATT, W.P. The evaluation of feeds through digestibility experiments. 1.ed. Athens: University of Georgia Press, 1975. 423p.

SILVA, D.J. Análise de alimentos (Métodos químicos e biológicos). 2.ed. Viçosa, MG: Universidade Federal de Viçosa, 1990. 165 p.
SILVA, L.D.F.; EZEQUIEL, J.M.B.; AZEVEDO, P.S. et al. Efeito da casca de soja e da fonte de nitrogênio sobre o consumo em novilhos alimentados com ração completa. In: REUNIÃO ANUAL DA SOCIEDADE BRASILEIRA DE ZOOTECNIA, 36., 1999, Porto Alegre. Anais... São Paulo: Gmosis, 1999. p.281. CD-ROM.

SILVA, L.D.F.; EZEQUIEL, J.M.B.; AZEVEDO, P.S. et al. Digestão total e parcial de alguns componentes de dietas contendo diferentes níveis de casca de soja e fontes de nitrogênio, em bovinos. Revista Brasileira de Zootecnia, v.31, n.3, p.1258-1268, 2002.

SILVA, A.V.; PEREIRA, O.G.; VALADARES FILHO, S.C. et al. Consumo e digestibilidades aparentes total e parcial de nutrientes, em bovinos recebendo rações contendo silagens de milho e sorgo, com ou sem inoculante microbiano. In: REUNIÃO ANUAL DA SOCIEDADE BRASILEIRA DE ZOOTECNIA, 38., 2001, Piracicaba. Anais... São Paulo: Sonopress, 2001. CD-ROM.

SNIFFEN, C.J.; O'CONNOR, J.D.; Van SOEST, P.J. et al. A net carbohydrate and protein system for evaluating cattle diets: II. Carbohydrate and protein availability. Journal of Animal Science, v.70, n.11, p.3562-3577, 1992.

TIBO, G.C.; VALADARES FILHO, S.C.; VALADARES, R.D. et al. Níveis de concentrado em dietas de novilhos mestiços F1 Simental x Nelore. 1. Consumo e digestibilidades. Revista Brasileira de Zootecnia, v.29, n.3, p.910-920, 2000.

VALADARES, R.F.D.; GONÇALVES, L.C.; RODRÍGUEZ, N.M. et al. Metodologia de coleta de urina em vacas utilizando sondas de Folley. Revista Brasileira de Zootecnia, v.26, n.6, p.1279-1282, 1997.

VALADARES FILHO, S.C.; COELHO DA SILVA, J.F.; LEÃO, M.I. et al. Óxido crômico e lignina na determinação dos fluxos de matéria seca abomasal, ileal e fecal em bovinos e bubalinos. Revista da Sociedade Brasileira de Zootecnia, v. 14, n.5, p.565-574, 1985.

VALADARES FILHO, S.C. Eficiência de síntese de proteína microbiana, degradação ruminal e digestibilidade intestinal da proteína bruta, em bovinos. In: SIMPÓSIO INTERNACIONAL SOBRE EXIGÊNCIAS NUTRICIONAIS DE RUMINANTES, 1, VIÇOSA, 1995. Anais... Viçosa, MG: Universidade Federal de Viçosa, 1995. p.354-388.

Van SOEST, P.J. Nutritional ecology of the ruminant. 2.ed. Ithaca:Cornell. 1994. 476p.

WALDO, D.R. Effect of forage quality on intake and forageconcentrate interactions. Journal of Dairy Science, v.69, n.4, p.617-631, 1986.

ZEOULA, L.M.; DIAN, P.H.M.; CALDAS NETO, S.F. et al. Avaliação de indicadores internos em ensaios de digestibilidade para ruminantes. In: REUNIÃO ANUAL DA SOCIEDADE BRASILEIRA DE ZOOTECNIA, 38., 2001. Piracicaba. Anais... São Paulo: Sonopress, 2001. CD-ROM.

ZEOULA, L.M.; CALDAS NETO, S.F. Recentes avanços na nutrição de vacas leiteiras. In: SIMPÓSIO INTERNACIONAL DE BOVINOCULTURA DE LEITE, 2001, Lavras, Lavras: Universidade Federal de Lavras, 2001. p.249-284. 